\title{
Effect of Different Sugars on Diarrhoea of Acute Kwashiorkor
}

\author{
J. G. PRINSLOO, W. WITTMANN, P. J. PRETORIUS, H. KRUGER, \\ and S. A. FELLINGHAM \\ From the National Nutrition Research Institute, Council for Scientific and Industrial Research, Pretoria; the Department \\ of Paediatrics, Medical School, University of Pretoria; and National Research Institute for Mathematical Sciences, \\ Council for Scientific and Industrial Research, Pretoria, South Africa
}

Children with kwashiorkor almost invariably have diarrhoea which may be severe and prolonged. The exact cause is often obscure and the management unsatisfactory (Brock et al., 1955; Trowell, 1958; Pretorius and Smit, 1958). Recently Bowie, Brinkman, and Hansen (1965), and Bowie, Barbezat, and Hansen (1967) found that the majority of their kwashiorkor patients with severe diarrhoea responded with a dramatic reduction in daily stool weights on a lactose-free diet, with or without added glucose. The diarrhoea was related to lactose malabsorption as a result of intestinal lactase deficiency. Other disaccharidases were much less affected, and absorption tests for sucrose and maltose were normal. In Uganda, Wharton (1968) found intolerance to disaccharides and glucose in kwashiorkor patients, and he was able to control the diarrhoea with a diet containing fructose as the only carbohydrate. The present investigation was undertaken to evaluate further the effect of different sugars on the diarrhoea of kwashiorkor in an area where life-threatening diarrhoea is less frequently encountered than reported from other centres (Pretorius, Wehmeyer, and Meÿ, 1964; Wharton, 1968).

\section{Material and Methods}

From August 1966 until March 1968, 120 Bantu male infants between 9 and 36 months of age suffering from kwashiorkor were studied in Pretoria at the Nutrition Clinic for Children. Though patients with severe kwashiorkor were included, those who appeared moribund or had obvious parenteral infections were excluded from the study. All children received the same supportive therapy after admission, including electrolyte solutions, a multivitamin syrup, supplementary potassium, and antibiotics by mouth. On the day after admission the children were allocated at random to 1 of 6 dietary regimens for a period of 13 days.

Received March 24, 1969.
The basic formula was identical in 5 groups. In 4 of the 5 groups different sugars were added, while one group received no additional sugar. The sixth group received reconstituted full-cream milk powder (Nespray). The diets are shown in Table I.

Enough of the formula was prepared to provide $150 \mathrm{ml} . / \mathrm{kg}$. per day. The casein-lactose formula (No. 2) had a lactose content of $6.3 \mathrm{~g} . / 100 \mathrm{ml}$., while the milk formula (No. 6) contained $4.8 \mathrm{~g}$. lactose/ $100 \mathrm{ml}$.

TABLE I

Composition of Diets in Different Groups

\begin{tabular}{|c|c|c|c|c|c|}
\hline \multicolumn{6}{|c|}{ Group } \\
\hline 1 & 2 & 3 & 4 & 5 & 6 \\
\hline $\begin{array}{c}F^{\star} \\
\text { Only }\end{array}$ & $\begin{array}{c}\mathrm{F}^{\star}+ \\
60 \mathrm{~g} . \\
\text { lactose }\end{array}$ & $\begin{array}{c}\mathrm{F}^{\star}+60 \mathrm{~g} . \\
\text { glucose }\end{array}$ & $\begin{array}{c}\mathrm{F}^{\star}+60 \mathrm{~g} . \\
\text { sucrose }\end{array}$ & $\begin{array}{c}\mathrm{F}^{\star}+60 \mathrm{~g} . \\
\text { dextrin- } \\
\text { maltose }\end{array}$ & $\begin{array}{c}\text { Nespray }+ \\
115 \mathrm{~g} .+ \\
800 \mathrm{ml} . \\
\text { water }\end{array}$ \\
\hline - & $\begin{array}{l}\text { an } 40 \\
\text { Cor } \\
\text { Ltd. } \\
\text { erals } \\
\text { isted } \\
\text { phate } \\
\text {, and } \\
=\text { full }\end{array}$ & $\begin{array}{l}\text { unflower } \\
\text { sition o } \\
\text { lcium ca } \\
\text { o, glyc } \\
\text { alcium } \\
\text {, dicalc } \\
\text { hesium s } \\
\text { m powd }\end{array}$ & $\begin{array}{l}\text { d oil } 40 \mathrm{~g} \\
\text { Casilan } \\
\text { nate } 90 \% \\
\text { mono-o } \\
\text { bonate } 10 \\
\text { phospha } \\
\text { hate } 10 \% \\
\text { d milk. }\end{array}$ & $\begin{array}{l}\text { water } 800 \\
\text { laxo-Allen } \\
\text { th } 1 \cdot 8 \%, \mathbf{n} \\
\text { te } 0 \cdot 4 \% \\
\text { dipotass } \\
15 \% \text {, sodi }\end{array}$ & $\begin{array}{l}\text { al., and salt } \\
\text { urys, S.A. } \\
\text { oisture } 4 \% \text {, } \\
\text { The salt } \\
\text { um hydro- } \\
\text { im chloride }\end{array}$ \\
\hline
\end{tabular}

After an adjustment period of 1 day, a 24-hour stool specimen was collected on a metabolic bed on the second day of the special diet (1st period). The collection was repeated on the 12th and 13th days after the special diet was introduced. The results obtained on these 2 days were combined, and the average per 24 hours was calculated (2nd period). The stool specimens were weighed and then frozen until analysed for lactic acid content according to the method of Barker and Summerson (1941).

The $p \mathrm{H}$ of a fresh stool specimen was determined with narrow-range $\mathrm{BDH} p \mathrm{H}$ paper on the collection days. A stool specimen of each patient was microscopically examined and cultured for salmonellae, shigellae, and enteropathogenic Esch. coli. The concentration of 
serum proteins was estimated on the first and last days of the experimental period in 111 of the 114 children according to standard procedures used in our laboratory (Prinsloo et al., 1967). During the experiment all patients, especially those in the 'no-sugar' group, were carefully observed for signs of hypoglycaemia. Fasting blood sugar levels were determined on the 3rd and 10th days after admission in 70 patients. A standard Technicon Auto-analyser was used, where glucose was determined by means of reduction of potassium ferricyanide, as originally described by Hoffman (1937).

A peroral small bowel biopsy was performed in 33 patients with the infant size Watson capsule from the region of the ligament of Treitz under fluoroscopic control with an image intensifier. Disaccharidase activity was immediately estimated according to the method of Dahlqvist (1964), and expressed per gram of mucosal protein (Lowry et al., 1951). A fresh sample of the duodenal aspirate was microscopically examined in all cases.

For purposes of comparison with normal children the weight of each child on admission was expressed as a percentage of the Boston 50th centile (Nelson, 1964).

Statistical analysis of the data (except for the disaccharidases) was carried out using the KruskalWallis one-way analysis of variance (Miller, 1966). A difference between the groups was considered significant when the probability level associated with the test was less than $5 \%$. When such a significant difference was found this was followed by a multiple comparisons test (Miller, 1966) to find between which pairs of groups differences existed.

\section{Results}

The number of patients in each dietary group, the mean age, and the mean percentage of expected weight for age are shown in Table II. The groups were comparable with respect to these parameters. The data obtained from 6 children were excluded from the study. 5 died ( 3 in group 3, and 1 each in groups 4 and 6), and the 6 th (in group 4) was found to be suffering from nephrosis in addition to malnutrition. Fig. 1 is a histogram of the mean values of stool weight and lactic acid per 24 hours for

TABLE II

Number of Patients, Mean Age, and Mean Percentage of Expected Weight in Each Dietary Group

\begin{tabular}{|c|c|c|c|}
\hline Dietary Group & No. & Age (mth.) & $\begin{array}{l}\% \text { Expected } \\
\text { Weight }\end{array}$ \\
\hline $\begin{array}{l}\text { 1. No sugar } \\
\text { 2. Lactose .. } \\
\text { 3. Glucose.. } \\
\text { 4. Sucrose } \\
\text { 5. Dextrin-maltose } \\
\text { 6. Milk .. }\end{array}$ & $\begin{array}{l}20 \\
20 \\
17 \\
18 \\
20 \\
19\end{array}$ & $\begin{array}{l}21 \\
22 \\
24 \\
23 \\
22 \\
20\end{array}$ & $\begin{array}{l}70 \\
68 \\
67 \\
73 \\
70 \\
66\end{array}$ \\
\hline
\end{tabular}

both periods, while the mean values and standard deviations for both periods are shown in Fig. 2 and 3. The results of the multiple comparisons tests for these data are shown in Table III. Those groups that did not differ significantly from each other have been underlined with a common line.

Initially, diarrhoea was most severe and lactic acid excretion highest in those groups (2 and 6) that received lactose in the diet (Fig. 1-3). In addition, these results were least predictable (as indicated by the high standard deviations) in the patients of these two groups as compared with those who did not receive lactose (groups 1, 3, 4, and 5). At the end of the experiment the diarrhoea of the patients in group 6 (full-cream milk) was considerably less severe than initially, though lactic acid excretion was still high and unpredictable. Group 2 patients, who had the highest intake of lactose, remained distinct from the patients in other groups in respect of both the severity of diarrhoea and the level of lactic acid excretion, and the scatter in the results of these observations (Fig. 2 and 3 ).

Table IV shows the mean daily stool weights and

TABLE III

Results of Multiple Comparisons Test on Stool Weights and Lactic Acid Excretion

\begin{tabular}{l|l|l}
\hline Stool Weight & $\begin{array}{l}\text { 1st Period } \\
\text { 2nd Period }\end{array}$ & 143526 \\
Lactic Acid & 1st Period & 4153626 \\
\hline
\end{tabular}

Groups which do not differ significantly from each other are underlined with a common line. Nos. 1-6 represent the different dietary groups. (See Table I.)

\section{TABLE IV}

Average Stool Weights and Incidence of Diarrhoea in the Various Groups at Beginning and at End of Experiment

\begin{tabular}{|c|c|c|c|c|}
\hline Dietary Group & $\begin{array}{c}\text { Average } \\
\text { Stool } \\
\text { Weight } \\
\text { (g./24 hr.) } \\
\text { First } \\
\text { Period }\end{array}$ & $\begin{array}{c}\% \text { With } \\
\text { Diarrhoea } \\
(>200 \text { g./ } \\
\text { day })\end{array}$ & $\begin{array}{l}\text { Average } \\
\text { Stool } \\
\text { Weight } \\
\text { (g./24 hr.) } \\
\text { Second } \\
\text { Period }\end{array}$ & $\begin{array}{c}\text { \% With } \\
\text { Diarrhoea } \\
(>200 \mathrm{~g} . / \\
\text { day })\end{array}$ \\
\hline $\begin{array}{l}\text { 1. No sugar } \quad \ldots \\
\text { 2. Lactose } \quad \ldots \\
\text { 3. Glucose } \quad \ldots \\
\text { 4. Sucrose } \quad \ldots \\
\text { 5. Dextrin-maltose } \\
\text { 6. Milk } \quad \text {.. }\end{array}$ & $\begin{array}{l}147 \\
455 \\
167 \\
163 \\
189 \\
413\end{array}$ & $\begin{array}{l}20 \\
75 \\
24 \\
22 \\
35 \\
79\end{array}$ & $\begin{array}{r}85 \\
295 \\
161 \\
125 \\
144 \\
155\end{array}$ & $\begin{array}{l}10 \\
70 \\
29 \\
22 \\
20 \\
16\end{array}$ \\
\hline
\end{tabular}




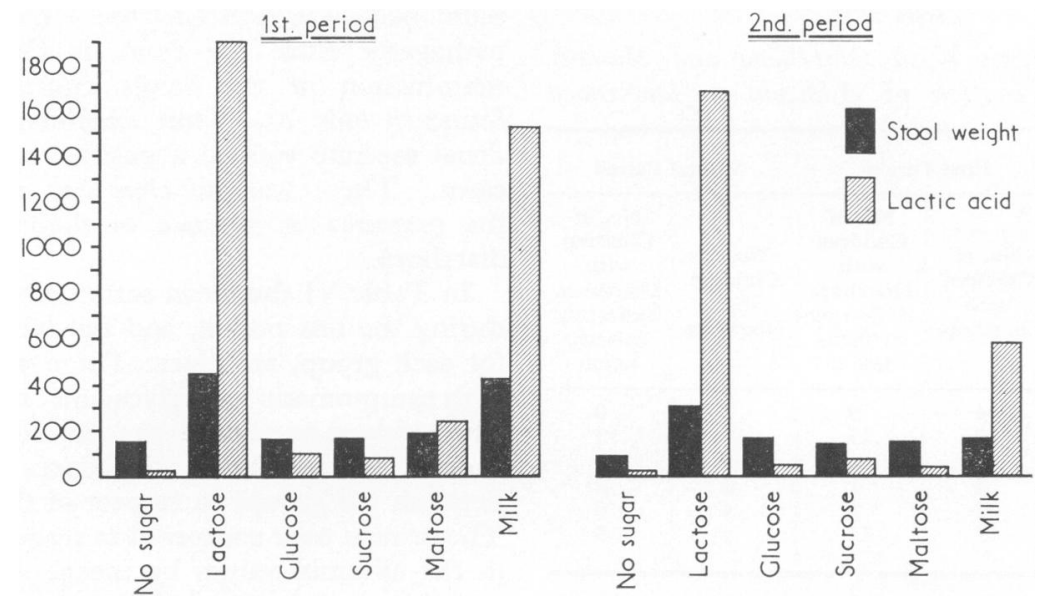

Fig. 1.- Mean stool weight (g./24 hr.) and mean lactic acid (mg./24 hr.) for each dietary group (note, maltose = dextrin-maltose).

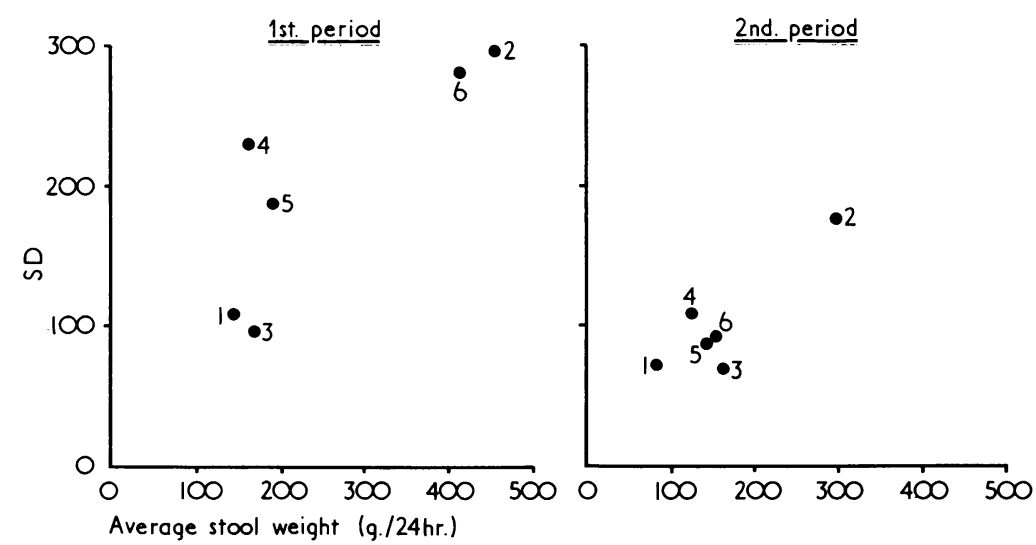

Fig. 2.-Mean stool weight (g./24 hr.) and standard deviation for the 6 dietary groups (for Nos. 1-6 see Table I).

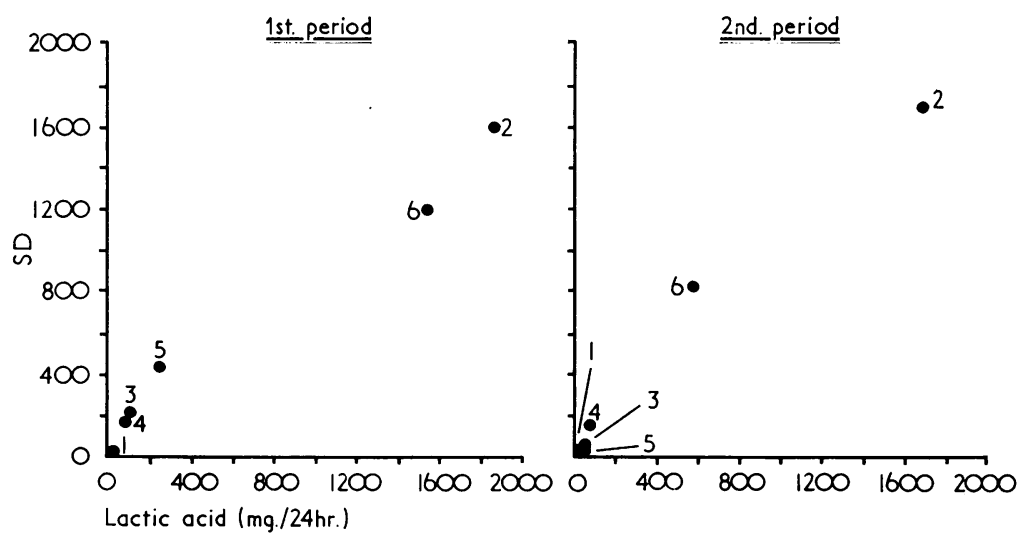

FIG. 3.-Mean lactic acid (mg./24 hr.) and standard deviation for the 6 dietary groups (for Nos. 1-6 see Table I). 
TABLE V

Number of Patients With Diarrhoea and Number Reflecting Fermentation in Addition to Diarrhoea

\begin{tabular}{|c|c|c|c|c|}
\hline \multirow[b]{2}{*}{ Group } & \multicolumn{2}{|c|}{ First Period } & \multicolumn{2}{|c|}{ Second Period } \\
\hline & $\begin{array}{l}\text { No. of } \\
\text { Children } \\
\text { with } \\
\text { Diarrhoea }\end{array}$ & $\begin{array}{l}\text { No. of } \\
\text { Children } \\
\text { with } \\
\text { Diarrhoea } \\
\text { Reflecting } \\
\text { Fermen- } \\
\text { tation }\end{array}$ & $\begin{array}{l}\text { No. of } \\
\text { Children } \\
\text { with } \\
\text { Diarrhoea }\end{array}$ & $\begin{array}{l}\text { No. of } \\
\text { Children } \\
\text { with } \\
\text { Diarrhoea } \\
\text { Reflecting } \\
\text { Fermen- } \\
\text { tation }\end{array}$ \\
\hline $\begin{array}{l}\text { 1. No sugar } \quad \ldots \\
\text { 2. Lactose } \quad \ldots \\
\text { 3. Glucose } \quad \ldots \\
\text { 4. Sucrose } \quad . \\
\text { 5. Dextrin-maltose } \\
\text { 6. Milk.. }\end{array}$ & $\begin{array}{r}4 \\
15 \\
4 \\
4 \\
7 \\
15\end{array}$ & $\begin{array}{r}0 \\
15 \\
1 \\
1 \\
2 \\
14\end{array}$ & $\begin{array}{r}2 \\
14 \\
5 \\
4 \\
4 \\
3\end{array}$ & $\begin{array}{r}0 \\
13 \\
0 \\
2 \\
0 \\
3\end{array}$ \\
\hline
\end{tabular}

the percentage incidence of diarrhoea before and after treatment.

In Table $\mathrm{V}$ the dietary groups are compared with regard to the incidence of diarrhoea and fermentation. Diarrhoea was arbitrarily defined as more than $200 \mathrm{~g}$. stool per 24 hours, and fermentation was considered to be present if the stool contained more than $200 \mathrm{mg}$. lactic acid per 24 hours. Diarrhoea was most severe and occurred most frequently in those patients who received lactose in the diet. During treatment the patients on the high lactose intake (group 2) showed little change in the incidence of diarrhoea and fermentation, though both became less severe. There was an improvement on both counts, however, in those who received milk (group 6). It needs to be added that, on the milk diet, at the end of the experiment there were 5 children with a raised lactic acid excretion without diarrhoea in addition to the 3 who had fermentation and diarrhoea.

Diarrhoea was less common and fermentation was rare if the diet contained no lactose. These groups $(1,3,4$, and 5$)$ showed very little change during treatment, though there was an over-all tendency towards improvement of diarrhoea. There was no statistical difference between them, but the group without sugar had the lowest incidence of diarrhoea and showed no evidence of fermentation.

The correlation between stool $p \mathrm{H}$ and lactic acid concentration was fairly good. In the present study the best division appeared to be at a $p H$ of about $5 \cdot 5$. Above $p \mathrm{H} 5 \cdot 5,84 \%$ of the specimens showed a normal lactic acid concentration, and below $p \mathrm{H} 5.5$ the lactic acid was raised in $70 \%$ of the samples. A high $p \mathrm{H}$ thus excluded fermentation more accurately than a low $p \mathrm{H}$ confirmed it.

The incidence of enteropathogens was low.
Salmonella was isolated from 7 stools and enteropathogenic Esch. coli from 8. On microscopical examination of the stools Giardia lamblia was found in only $7 \%$, while examination of the duodenal aspirate yielded a positive result in $87 \%$ of cases. There was no clear-cut relation between the presence or absence of these pathogens and diarrhoea.

In Table VI the mean serum albumin increment during the test period, and the blood sugar values for each group, are given. There were no children with symptomatic hypoglycaemia, not even in those who received no sugar in the diet. Statistical analysis showed no significant differences at a 5\% level between the groups in respect of the blood sugars. The groups were compared in respect of the change in the albumin values by means of an analysis of covariance (Scheffé, 1959) so as to remove the possible effect of differences in initial serum albumin concentration on the change in the values.

\section{TABLE VI}

Serum Albumin Increments of Different Groups during Experimental Period and Initial and Final Blood Sugar Values

\begin{tabular}{|c|c|c|c|}
\hline \multirow[t]{2}{*}{ Dietary Group } & \multirow{2}{*}{$\begin{array}{c}\text { Mean Albu- } \\
\text { min } \\
\text { Increment } \\
(\mathrm{g} . / 100 \mathrm{ml} .)\end{array}$} & \multicolumn{2}{|c|}{$\begin{array}{l}\text { Mean Blood Sugar and Range } \\
(\mathrm{mg} . / 100 \mathrm{ml} .)\end{array}$} \\
\hline & & Initial & Final \\
\hline $\begin{array}{l}\text { 1. No sugar } \ldots \\
\text { 2. Lactose } \\
\text { 3. Glucose } \quad \ldots \\
\text { 4. Sucrose } \\
\text { 5. Dextrin-maltose } \\
\text { 6. Milk .. }\end{array}$ & $\begin{array}{l}1 \cdot 19 \\
1 \cdot 48 \\
1 \cdot 23 \\
1 \cdot 24 \\
1 \cdot 10 \\
1 \cdot 35\end{array}$ & $\begin{array}{c}85 \\
(54-137) \\
89 \\
(70-110) \\
94 \\
(50-120) \\
94 \\
(67-124) \\
94 \\
(63-148) \\
87 \\
(70-100)\end{array}$ & $\begin{array}{c}87 \\
(58-108) \\
91 \\
(70-117) \\
80 \\
(69-95) \\
92 \\
(67-115) \\
81 \\
(61-97) \\
93 \\
(72-126)\end{array}$ \\
\hline
\end{tabular}

No significant differences between the groups were found. The albumin increment was, however, highest in those patients who received lactose.

Though not significant, these higher albumin increments seemed paradoxical since the lactose groups had the most severe diarrhoea. It is unlikely that latent dehydration (due to the increased diarrhoea) resulted in the slightly higher albumin values, since statistical analysis of the change in weight over the experimental period did not reveal any significant differences between the groups.

In Table VII the results of disaccharidase assays are compared with normal values in children obtained from previously published results (Burke, 
TABLE VII

Disaccharidase Levels in Small Bowel Biopsy of 33 Patients in Comparison With 'Normal' Values (Mean and Range)

\begin{tabular}{|c|c|c|c|c|}
\hline & & $\begin{array}{l}\text { Disaccharidases } \\
\text { of } 33 \text { Patients } \\
\text { ( } \mu \text { mole/g. pro- } \\
\text { tein per min.) }\end{array}$ & $\begin{array}{l}\text { Percentage of } \\
\text { 'Normal' } \\
\text { Values }\end{array}$ & $\begin{array}{c}\text { 'Normal' } \\
\text { Values } \\
\text { (Burke, 1965) }\end{array}$ \\
\hline Lactase & .. & $\begin{array}{c}7 \\
(1-17)\end{array}$ & 14 & $\begin{array}{c}49 \\
(14-132)\end{array}$ \\
\hline Sucrase & $\ldots$ & $\begin{array}{c}35 \\
(5-71)\end{array}$ & 37 & $\begin{array}{c}95 \\
(32-228)\end{array}$ \\
\hline Isomaltase & . & $\begin{array}{c}51 \\
(3-118)\end{array}$ & 57 & $\begin{array}{c}89 \\
(31-177)\end{array}$ \\
\hline Maltase & . & $\begin{array}{c}100 \\
(0-226)\end{array}$ & 38 & $\begin{array}{c}260 \\
(83-615)\end{array}$ \\
\hline
\end{tabular}

Kerry, and Anderson, 1965). In most patients a general depression of disaccharidase activity was found, with lactase the most severely diminished. One child had absence of maltase activity which was confirmed by a repeat biopsy after 3 days. A third biopsy after 3 weeks showed considerable improvement. The biopsies were not repeated on the other patients in this series.

\section{Comment}

It is obvious that lactose intolerance in our area, as elsewhere, is an important factor in the complex aetiology of the diarrhoea of kwashiorkor patients. These results confirm much of the previous work, but some interesting additional points have also emerged. In general, diarrhoea appears to be less severe in the Pretoria area than for example in Cape Town (Hansen, 1968) or Kampala (Wharton, Howells, and Phillips, 1968), though lactose intolerance is common throughout. Diarrhoea is almost certainly caused by more than one factor, at least in some cases. Lactose intolerance, however, appears to be the most important single cause. Even on admission there is a clearcut difference in the incidence and severity of diarrhoea between those patients who receive lactose and those who receive other sugars in their diets. Evidence of fermentation, i.e. a high lactic acid excretion, is common in patients on lactose and much less common in patients receiving other sugars. Both the stool weights and lactic acid contents are lowest if no sugar is added to the diet. In Fig. 2 and 3 the groups form two clusters in the first period, with both lactose groups clearly separated from the other, which are similar to one another.

In the 2nd period, group 6 (whole milk) seemed to have joined the main cluster formed by groups $1,3,4$, and 5 in respect of stool weights, and to have moved halfway towards this cluster in respect of lactic acid (Fig. 2 and 3). The large standard deviations explain why big differences between average values of members of these two clusters are not necessarily statistically significant. It can be argued that a good response to treatment would be reflected by low stool weights and little lactic acid excretion (i.e. if the mean values of the treatment groups are low and if the standard deviation for a group is small). Applying these criteria, the diets given to groups $1,3,4$, and 5 (i.e. no sugar, glucose, sucrose, dextrin-maltose) seem to be more or less equally acceptable. There was an adverse reaction in diet groups 2 and 6 initially (both containing lactose, $6.3 \%$ and $4.8 \%$, respectively), with group 6 (milk) acceptable in the second period, if judged by the reduced stool weights.

The results also indicate that during treatment sugar tolerance improved, since stool weights and lactic acid excretion dropped in all the groups. The difference between groups 2 and 6 may be due to the fact that the patients in the former group had a higher lactose load $(6 \cdot 3 \%)$ than those on milk $(4 \cdot 8 \%)$. It is well known that kwashiorkor patients in general do improve on a milk diet, and this was confirmed by the present study. On the milk diet diarrhoea persisted in only about onethird of patients ( 3 out of 8 ) who had continued evidence of lactose malabsorption. It is interesting to note that the diarrhoea and fermentation, though less severe than on admission, tended to persist on the higher lactose intake. Lactose malabsorption is thus not necessarily associated with diarrhoea, and the association is influenced at least in part by the amount of sugar in the diet.

The results of the enzyme assays are generally in agreement with previously reported values in protein-calorie malnutrition (Bowie et al., 1967). Though biopsies were not repeated in the present series, disaccharidase levels are still diminished in children with kwashiorkor and pellagra 6 to 8 weeks after admission and after clinical cure (unpublished data). It is not known how long these abnormalities will persist or whether lactase is more permanently affected than the other enzymes. The disproportionate lactase deficiency may be due to genetic factors in addition to the influence of malnutrition and infection (Cook, Lakin, and Whitehead, 1967).

The severe depression of lactase activity correlates well with the clinical evidence of lactose intolerance. Chandra, Pawa, and Ghai (1968) found sucrose malabsorption on oral tolerance tests 
in $25 \%$ of their patients. In the present series, however, the less severe depression of the disaccharidases, other than lactase, did not appear to be of great practical significance with regard to diarrhoea and lactic acid excretion.

The mortality rate of kwashiorkor patients varies between 11 and $50 \%$ (Walt, Wills, and Nightingale, 1950; Lawless, Lawless, and Garden, 1966). The exceptionally low mortality of $4.2 \%$ in this series is most probably due to the exclusion of moribund cases from the experimental group. Nevertheless, the over-all mortality of kwashiorkor patients admitted to our unit over the past 3 years has also been low, namely $9 \%$, which is ascribed more to specialized nursing and careful observation than to any specific therapeutic regimen.

Thus, in general, acute kwashiorkor patients in the Pretoria area were found to tolerate milk sufficiently well for initiation of cure. Though a lactose-free formula is not routinely indicated, for individual patients it may be necessary to remove lactose from the diet. Among the sugars tested, sucrose appears to be the logical substitute, since it is well tolerated, easily available, and cheap. Wharton et al. (1968) also recommend sucrose where a lactose-free diet is indicated, and if this is also tolerated poorly, they use fructose instead. Nevertheless, there was no difference between our groups receiving different dietary sugars with regard to initiation of cure (clinical state, loss of oedema, weight gain, and serum albumin regeneration).

\section{Summary and Conclusions}

The effect of different dietary sugars on diarrhoea in kwashiorkor patients was tested over 13 days in 6 groups of about 20 patients each. In 5 groups the diet consisted of a basic casein formula, with the addition of $6.3 \%$ of either glucose, sucrose, dextrin-maltose, lactose, or no sugar. The 6 th group received cow's milk $(4 \cdot 8 \%$ lactose). The patients in the groups which received lactose had initially more severe diarrhoea and higher lactic acid excretion than the patients in the other groups. Diarrhoea improved in all groups over the experimental period, but the incidence of diarrhoea and abnormal lactic acid excretion in the group receiving the $6 \cdot 3 \%$ lactose formula was still high at the end of the experimental period. On the other hand the group on cow's milk ( $4.8 \%$ lactose), in spite of high lactic acid excretion, did not have more diarrhoea than the other groups at the end of the experimental period. It seemed that there was a threshold for lactose tolerance and that tolerance improved during initiation of cure. There were no significant differences between the stool weights and lactic acid excretion of the other groups, either at the beginning or at the end of the experiment.

Initiation of cure, whether judged clinically or by disappearance of oedema, weight change, or albumin regeneration, did not differ among the groups.

Intestinal biopsies and disaccharidase assays done in 33 patients showed a depression of all enzyme activities, especially lactase.

It is concluded that in the Pretoria area milk is generally tolerated sufficiently well for initiation of cure in kwashiorkor patients, so that a lactose free formula is not routinely indicated. In individual patients, however, it may be necessary to exclude lactose, in which case sucrose is the logical choice, since it is easily available, inexpensive, and well tolerated.

We wish to thank Miss I. Scharffenorth and Mrs. E. Freier for technical assistance, and Professor L. S. de Villiers of the Institute of Pathology, University of Pretoria, for the serum protein and blood sugar determinations.

\section{REFERENCES}

Barker, S. B., and Summerson, W. H. (1941). The colorimetric determination of lactic acid in biological material. $\mathcal{F}$. biol. Chem., 138, 535.

Bowie, M. D., Barbezat, G. O., and Hansen, J. D. L. (1967). Carbohydrate absorption in malnourished children. Amer. f. clin. Nutr., 20, 89.

_- Brinkman, G. L., and Hansen, J. D. L. (1965). Acquired disaccharide intolerance in malnutrition. $\mathcal{F}$. Pediat., 66, 1083.

Brock, J. F., Hansen, J. D. L., Howe, E. E., Pretorius, P. J., Davel, J. G. A., and Hendrickse, R. G. (1955). Kwashiorkor and protein malnutrition. A dietary therapeutic trial. Lancet, 2, 355.

Burke, V., Kerry, K. R., and Anderson, C. M. (1965). The relationship of dietary lactose to refractory diarrhoea in infancy. Aust. paediat. ., 1, 147.

Chandra, R. K., Pawa, R. R., and Ghai, O. P. (1968). Sugar intolerance in malnourished infants and children. Brit. med. F. 4, 611 .

Cook, G. C., Lakin, A., and Whitehead, R. G. (1967). Absorption of lactose and its digestion products in the normal and malnourished Ugandan. Gut, 8, 622 .

Dahlqvist, A. (1964). Method for assay of intestinal disaccharidases. Analyt. Biochem., 7, 18.

Hansen, J. D. L. (1968). Features and treatment of kwashiorkor at the Cape. In Calorie Deficiencies and Protein Deficiencies, p. 33. Ed. by R. A. McCance and E. M. Widdowson. Churchill, London.

Hoffman, W. S. (1937). A rapid photoelectric method for the determination of glucose in blood and urine. $\mathcal{F}$. biol. Chem., $120,51$.

Lawless, J., Lawless, M. M., and Garden, A. S. (1966). Admissions and mortality in a children's ward in an urban tropical hospital. Lancet, 2, 1175.

Lowry, O. H., Rosebrough, N. J., Farr, A. L., and Randall, R. J. (1951). Protein measurement with the Folin phenol reagent. F. biol. Chem., 193, 265.

Miller, G. R. (1966). Simultaneous Statistical Inference, p. 165. McGraw-Hill, New York.

Nelson, W. E. (1964). Textbook of Pediatrics, 8th ed., p. 48 Saunders, Philadelphia and London. 
Pretorius, P. J., and Smit, Z. M. (1958). The effect of various skimmed milk formulae on the diarrhoea, nitrogen retention and initiation of cure in kwashiorkor. F. trop. Pediat., 4, 50. , Wehmeyer, A. S., and Meÿ, H. S. (1964). The effect of milk fat and sunflower-seed oil on the diarrhoea, the nitrogen, the fat and mineral balance, and the rate of recovery, of kwashiorkor patients. S. Afr. med. F., 10, 21 .

Prinsloo, J. G., Pretorius, P. J., Wehmeyer, A. S, de Villiers, L. S. Fellingham, S. A., and Kruger, H. (1967). Effect of a lowprotein milk powder formula on the initiation of cure in kwashiorkor patients. Amer. F. clin. Nutr., 20, 270.

Scheffé, H. (1959). The Analysis of Variance, p. 192. John Wiley, New York.

Trowell, H. C. (1958). Kwashiorkor. In Diseases of Children in the Subtropics and Tropics, p. 171. Ed. by H. C. Trowell and D. B. Jelliffe. E. Arnold, London.
Walt, F., Wills, L., and Nightingale, R. P. (1950). Malignant malnutrition. S. Afr. med. F., 24, 920.

Wharton, B. A. (1968). Difficulties in the initial treatment of kwashiorkor. In Calorie Deficiencies and Protein Deficiencies, p. 147. Ed. by R. A. McCance and E. M. Widdowson. Churchill, London.

- Howells, G., and Phillips, I. (1968). Diarrhoea in kwashiorkor. Brit. med. F., 4, 608 .

Correspondence to Dr. J. G. Prinsloo, National Nutrition Research Institute of the South African Council for Scientific and Industrial Research, P.O. Box 395, Pretoria, South Africa. 